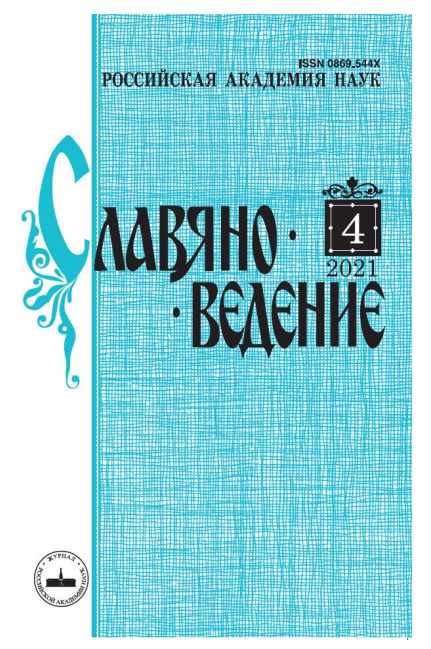

Славяноведение 2013-2023

ISSN 2079-8784

URL - $\underline{\text { http://ras.jes.su }}$

Все права защищены

Номер 4 Том . 2021

\title{
J. M. Bak, G. Pálffy. Crown and Coronation in Hungary 1000-1916 A.D.
}

\section{Хаванова Ольга Владимировна}

Заместитель директора по научной работе Института славяноведения РАН, Институт славяноведения РАН

Москва, Российская Федерация

Аннотация

Ключевые слова:

Дата публикации: 06.08.2021

Ссылка для цитирования:

Хаванова О. В. J. M. Bak, G. Pálffy. Crown and Coronation in Hungary 1000-1916 A.D. // Славяноведение - 2021. - Номер 4 C. 127-129 [Электронный ресурс]. URL: https://slav.jes.su/S0869544X0015975-5-1 (дата обращения: 26.04.2023). DOI: $10.31857 / \mathrm{S} 0869544 \mathrm{X} 0015975-5$

1 С 2012 г. в Венгрии действует программа академической мобильности «Импульс» («Lendület»/«Momentum»), в рамках которой на срочной или бессрочной основе финансируются масштабные проекты в разных областях наук. В числе заявленных целей - развитие диалога науки и общества, пропаганда достижений венгерских ученых в стране и за ее пределами. Одним из первых поддержанных и по сей день успешно действующих проектов стал «Святая корона» на базе Центра гуманитарных исследований Венгерской академии наук (с 2019 г. - Исследовательского центра им. Л. Этвеша). В рамках проекта в 2020 г. вышла в свет монография на английском языке медиевиста Я.М. Бака (1929-2020) и специалиста по истории раннего Нового времени, руководителя проекта Г. 
Палфи «Корона и коронации в Венгрии 1000-1916 гг.». Это синтетическая научная работа - первая столь подробнаяна английском языке, основанная на результатах новейших исследований. В силу детально проработанной структуры, богатой фактографии, высококачественных иллюстраций книга будет интересна широкой читательской аудитории во всем мире.

2 Книга состоит из краткого предисловия, трех разделов, посвященных порядку наследования, церемонии коронации и судьбе инсигний, и заключения; в приложение вошли хронологическая таблица коронаций и перемещений святой венгерской короны, избранная библиография, именной указатель и список правообладателей иллюстраций, которыми богато снабжено издание. Временные рамки книги- от условного 1000 г., когда Венгрия при первом короле ИштванеI приняла христианство, о чем известно по скупым свидетельствам позднейших хроник, до 1916 г. - последней в истории страны коронации императора Карла IГабсбурга венгерским королем под именем Карла IV, от которой до наших дней дошел массив письменных источников официального и личного происхождения, фото- и кинодокументов. Между двумя датами около 60 коронаций 52 королей (некоторые короновались несколько раз) и двух правящих королев. На протяжении столетий менялась юридическо-правовая база, появлялся все более детальный церемониал, создавались материальные объекты высокой художественной ценности, приобретавшие в силу традиции сакральный смысл.

3 Первый раздел знакомит читателя с эволюцией практики престолонаследования. В ранние века венгерской государственности сосуществовали, сменяя друг друга, принципы широко понимаемого родства с правителем и старшинства в правящем доме. В эпоху чередования иноземных династий в XIV - начале XVI в. (Анжу, Люксембурги, Ягеллоны и др.) вопрос престолонаследия решался выборами при все более активном участии высшей знати, а затем и шире - сословий королевства. С воцарением Габсбургов в 15261527 гг. выборы короля сначала ограничились одной династией, а затем, в 1687 г., и сам институт выборности был отменен, при этом XVI-XVII вв. Венгрия относилась к немногим странам Европы, где одновременно реализовывались принципы выборности и наследственности.

4 Во втором разделе предлагается обзор истории коронаций: от самых ранних в Эстергоме и Секешфехерваре и до более поздних в Пресбурге (совр. Братислава), Шопроне и Буде/Будапеште. Ученые обратили внимание, что церемонии приурочивались к субботам или воскресеньям, дням церковных праздников и поминовения значимых святых. Особой популярностью в эпоху барокко пользовались праздники богородичного цикла, поскольку Дева Мария считалась покровительницей Венгрии. Для XI-XII вв. не сохранилось практически никаких достоверных, не говоря уже о созданных очевидцами, записей церемонии коронации и инаугурационного помазания. Более или менее подробные описания имеются для вступления на престол Альбрехта Габсбурга в 1438 г. После 1526 г. закрепившийся на венгерском престоле Австрийский дом всячески демонстрировал преемственность с государственной традицией, поэтому в их коронациях сохранилось много элементов, отсылающих к практикам более ранних веков. Характерно, что известные историкам случаи ношения короны имели место в исключительных ситуациях демонстрации суверенитета, превосходства перед 
другими правителями или восставшими подданными. Начиная с 1638 г. все случаи извлечения короны из сундука, где она обычно хранилась, строго документировались. Среди регулярных поводов значатся и коронации королев церемонии с особым регламентом.

5 Средневековая Венгрия не знала права наследования земельной собственности по женской линии, это отразилось на порядке и практике наследования: когда в 1382 г. дочь Людовика (Лайоша) Анжуйского взошла на престол, она была коронована королем. История повторилась в 1741 г., когда венгерские сословия прокричали Марии Терезии: «Жизнь и кровь за нашего короля». Для супруг королей после 1563 г. постепенно сложился особый коронационный церемониал, символическим элементом которого со временем стало прикосновение венгерской короной к правому плечу королевы в знак того, что она - опора короля. Ее чело украшала особая, «королевина» корона.

6 Свидетелями актов коронации и помазания был ограниченный круг высших должностных лиц и иностранных послов, на коронационном банкете уже присутствовали представители сословий, двора, и дипломатического корпуса, самым массовым и зрелищным элементом оставалась торжественная процессия в церковь, где проходила церемония. По мере изменения соотношения сил между королем и сословиями все большее значение приобретала коронационная присяга, восходившая к мифической клятве кровью вождей семи племен, пришедших в Карпато-Дунайский бассейн в конце IX в. Ее содержание менялось в зависимости от конкретной политической ситуации и в целом отражало не прекращавшийся диалог сословий с королевской властью о государственно-правовых принципах управления страной.

7 В третьем разделе систематически описаны материальные объекты (регалии или инсигнии), участвовавшие в коронации: корона, мантия, меч, скипетр, держава, кресты, штандарты, перчатки, башмаки, в которые перед коронацией облачался король и др. Церемония считалась легитимной, если архиепископ Эстергомский возлагал на чело короля святую венгерскую корону в одном из городов королевства. Начиная с 1427 г. в коронации мог участвовать надор (королевский наместник), с 1687 г. его участие стало обязательным. Возможно, в память о кочевом прошлом и в силу того, что требования коронации в одном конкретном городе так и не оформилось, церемония не была связана с каким-то определенным троном.

8 Святая венгерская корона - это регалия, окруженная мифами, вызывающая непреходящий интерес как у ученых, так и в широких кругах любителей истории. В книге дан краткий обзор достоверной на сегодняшний день информации о времени создания «латинской» и «греческой» корон и их соединения в единое целое. Установлен год, когда в результате механического воздействия при попытке открыть ларец с короной, крест, по всей вероятности, был погнут и уже не мог быть выправлен - 1638. С превращением короны в регалию, безусловно легитимирующую королевскую власть, она стала объектом притязаний, краж, торговли и обмена, неоднократно покидала территорию Венгрии, пролежала в земле четыре года, зарытая в укромном месте после поражения национальноосвободительной войны 1849 г., после Второй мировой войны путешествовала 
через океан в США и в 1978 г. обратно. Идеологическое оформление ее исключительного места в государственно-правовой системе получило продолжение в лжеучениях о ее мистической силе.

9 Авторы пришли к выводу, что сформировавшиеся в стране за девять веков практики коронаций в основе имели более раннюю христианскую традицию, обладали рядом сходств с церемониями, нормами и обычаями соседних и типологически схожих монархий Чехии и Польши, но в то же время отличались от них в существенных деталях. Венгрия, по их мнению, стала мостом между западом и востоком континента, обрела с веками во многом уникальную политическую культуру, центральную роль в которой заняла венгерская корона.

10 Активное использование исследовательского опыта и научных достижений обоих авторов при создании синтетического труда стало залогом высокого качества научного текста: он терминологически и фактографически выверен, не перегружен лишними подробностями, но дополнен интересными, запоминающимися деталями. Логичная структура облегчает поиск по содержанию необходимой информации по частным вопросам, будь то коронационные столицы, королевские браки, процессии и пиры, история отдельных инсигний и др.

11 Книга станет незаменимым справочным и методическим пособием как при обращении историков к сюжетам, связанным с коронациями венгерских королей, так и в преподавании истории Венгрии с древнейших времен до 1916 г. В ней даны выверенная терминология на английском языке для важнейших понятий по теме короны и коронаций, имеются отсылки к основным письменным источникам и исследовательским работам.

\section{Библиография:}

1. 


\section{J. M. Bak, G. Pálffy. Crown and Coronation in Hungary 1000-1916 A.D.}

\section{Olga Khavanova}

Deputy Director of the Institute of Slavic Studies of the RAS, Deputy Director for Research of the Institute of Slavic Studies of the Russian Academy of Sciences Moscow, Russian Federation

Abstract

Keywords:

Publication date: 06.08 .2021

\section{Citation link:}

Khavanova O. J. M. Bak, G. Pálffy. Crown and Coronation in Hungary 1000-1916 A.D. // Slavianovedenie - 2021. - Issue 4 C. 127-129 [Electronic resource]. URL: https://slav.jes.su/S0869544X0015975-5-1 (circulation date: 26.04.2023). DOI: 10.31857/S0869544X0015975-5

Код пользователя: 0; Дата выгрузки: 26.04.2023; URL - http://ras.jes.su/slav/s0869544x0015975-5-1 Bсе права защищены. 